\title{
Active ingestion of fluorescently labeled bacteria by mesopelagic heterotrophic nanoflagellates in the East Sea, Korea
}

\author{
Byung Cheol Cho*, Sang Cheol Na, Dong Han Choi \\ School of Earth and Environmental Sciences and Research Institute of Oceanography, Seoul National University, \\ Shin-lim Dong, Kwan-ak Gu, Seoul 151-742, Republic of Korea
}

\begin{abstract}
To determine whether heterotrophic nanoflagellates (HNF) in the mesopelagial actively ingest bacteria and whether HNF grazing rates comprise a significant fraction of the mesopelagic bacterial production, we measured uptake rates of fluorescently labeled bacteria (FLB) by mesopelagic HNF and bacterial production in the East Sea, 5 times from April 1996 to September 1997. Although bacterial abundance and production were much lower in the mesopelagic than in the epipelagic zone, HNF clearance rates and volume-specific HNF clearance rates in both layers were usually within the same range, 1 to $11 \mathrm{nl} \mathrm{HNF}^{-1} \mathrm{~h}^{-1}$ and 0.1 to $1 \times 10^{6} \mathrm{~h}^{-1}$, respectively. Two samples in the mesopelagial showed somewhat increased clearance rates (14 to $16 \mathrm{nl} \mathrm{HNF}^{-1} \mathrm{~h}^{-1}$ ) and volumespecific HNF clearance rates (up to $2.6 \times 10^{6} \mathrm{~h}^{-1}$ ). Fractions of actively grazing HNF were not statistically different in the 2 layers (epipelagial: 33 to $98 \%$, mesopelagial: 22 to $79 \%$ ) in most cruises. HNF

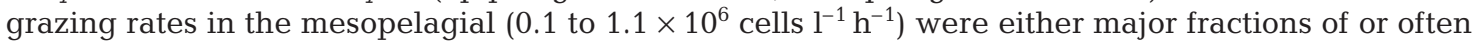
greater than bacterial production, suggesting that HNF grazing on bacteria was the major fate of mesopelagic bacterial production at the study site.
\end{abstract}

KEY WORDS: Heterotrophic nanoflagellates · Grazing $\cdot$ FLB $\cdot$ Mesopelagic zone $\cdot$ The East Sea

\section{INTRODUCTION}

Bacteria in the mesopelagial have been recognized as playing major roles in organic matter fluxes originating in the euphotic zone (Cho \& Azam 1988, 1995, Simon et al. 1992). However, significantly less information is available about the fate of bacteria in the mesopelagic zone (Turley 1991). Viruses are thought to be significant in regulating attached bacteria in the mesopelagial (Proctor \& Fuhrman 1991). However, freeliving bacteria comprise the majority of bacterial abundance in the mesopelagial (Cho \& Azam 1988, 1995). Recently, Steward et al. (1996) presented evidence that viruses may cause substantial mortality of mesopelagic

*E-mail: bccho@plaza.snu.ac.kr bacterioplankton, but other sources may contribute as well. Several studies reported the ubiquitous occurrence of heterotrophic nanoflagellates (HNF) in the mesopelagial (Pomeroy \& Johannes 1968, Taylor et al. 1986, Cho \& Azam 1988, Steward et al. 1996). However, nothing is known about their grazing impact on bacterioplankton. Because HNF are known as major grazers of marine bacteria in epipelagic environments (Sanders et al. 1992, Peters 1994), they may be also important bacterial grazers, controlling the growth of bacterioplankton communities in the mesopelagial.

The goals of this study were to examine whether HNF in the mesopelagic zone actively ingest bacteria, to quantify the fraction of the mesopelagic bacterial production consumed by HNF, and to determine factors that control bacteria-HNF interactions in the mesopelagic zone. 


\section{MATERIALS AND METHODS}

Study area and sample collection. During 5 cruises in the East Sea (Fig. 1), seawater samples were collected with 101 Niskin bottles mounted on a CTDrosette from $0,10,20,30,50,75,100,200$ and $500 \mathrm{~m}$ depths. In April 1996, an additional sample was taken at a depth of $180 \mathrm{~m}$. Samples collected from a depth interval of 200 to $500 \mathrm{~m}$ are regarded as mesopelagic samples. As the euphotic depth was in most cases shallower than $50 \mathrm{~m}$ depth in the East Sea, our choice seemed to fit the concept of mesopelagic zone (Young 1983). Each sample was used for determining HNF abundance, HNF grazing rates on bacteria, bacterial abundance and bacterial production.

HNF abundances, grazing rates of $\mathrm{HNF}$, and fractions of active HNF. Samples for measurements of HNF abundance were fixed immediately with alkaline Lugol solution (final conc. of $0.5 \%$ ) and boratebuffered formalin (final conc. of $3 \%$; Sherr et al. 1989, Rassoulzadegan 1991). Five to $15 \mathrm{ml}$ of seawater was stained with primulin (final conc. of $250 \mu \mathrm{g} \mathrm{ml}^{-1}$ ), and collected on a black $0.4 \mu \mathrm{m}$ polycarbonate filter $(25 \mathrm{~mm}$ diameter) at a vacuum not exceeding $100 \mathrm{~mm} \mathrm{Hg}$ (Caron 1983). Primulin-stained cells were visualized and enumerated at $\times 1000$ magnification with UV exci-

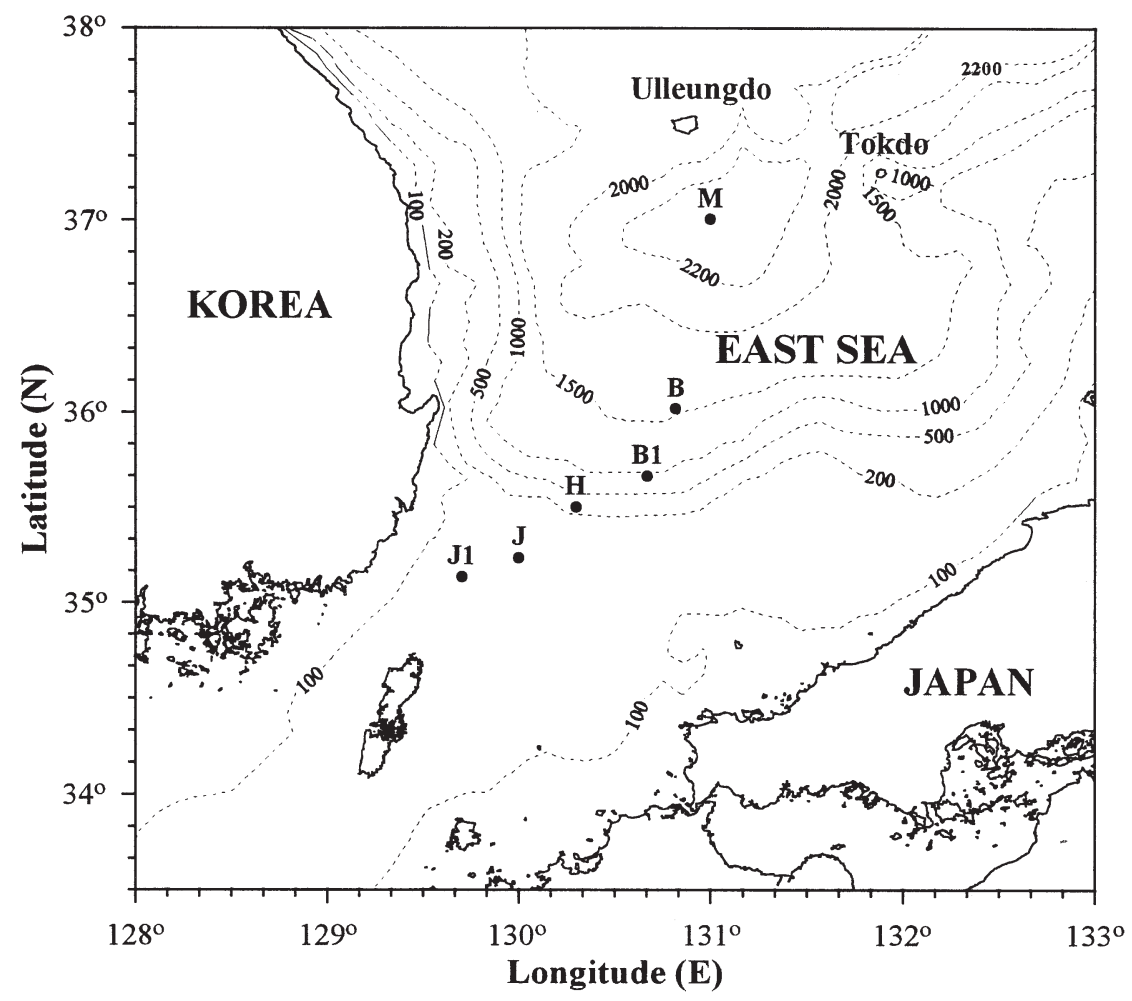

Fig. 1. Map of study area and sampling stations (M, B, B1, H, J, J1) in East Sea. Depth contour lines are shown in meters tation using an epifluorescence microscope (Olympus BX60 with U-MWU filter set, BP330-385 excitation filter, DM400 dichroic mirror, and BA420 barrier filter). Heterotrophic flagellates fluoresced bluish-white under UV excitation, while autotrophic flagellates were distinguished from heterotrophs by red autofluorescence under blue excitation (Olympus filter set U-MWB, BP450-480 excitation filter, DM500 dichroic mirror, and BA515 barrier filter). To calculate biovolume of HNF, both the short and long axes of HNF were measured, and a minimum of 100 microscopic fields or 30 cells were counted.

Measurements of HNF grazing rates on bacteria were made using fluorescently labeled bacteria (FLB). FLB were prepared by staining natural bacterial samples collected 3 to $5 \mathrm{~d}$ prior to each cruise from coastal waters in the East Sea with 5-(4,6-dichlorotriazin-2-yl) aminofluorescein (DTAF) according to Sherr et al. (1987). FLB uptake experiments were carried out in duplicate in $250 \mathrm{ml}$ polycarbonate bottles presoaked in $10 \%$ (vol/vol) $\mathrm{HCl}$ and copiously rinsed with deionized water. To $250 \mathrm{ml}$ samples, ca $1 \mathrm{ml}$ of the FLB stock was added. The added concentration of FLB was between 5 to $31 \%$ of bacterial abundance. Grazing experiments were conducted in the dark, at in situ temperature, and atmospheric pressure. Thirty $\mathrm{ml}$ of subsamples were collected at 0, 10, 20 and $30 \mathrm{~min}$, fixed, and kept refrigerated until microscopic examinations. Subsamples were primulin-stained and filtered, and at least 100 microscopic fields were counted. The filters were first observed under UV excitation at a magnification of $\times 1000$. When an HNF was located, the incident light was changed to blue, which allowed us to count the FLB contained within the HNF. The FLB fluoresced a bright apple green under blue light.

We calculated the number of ingested FLB $\mathrm{l}^{-1} \mathrm{~h}^{-1}$ from the slope of ingested FLB $\mathrm{l}^{-1}$ versus incubation time for each bottle. Average values of ingested FLB $\mathrm{l}^{-1} \mathrm{~h}^{-1}$ were calculated for duplicate bottles. Bacterivory rates were measured over the linear portion of the uptake curve, and the uptake was linear for ca $30 \mathrm{~min}$. The coefficoent of variation $(=100 \times \mathrm{SD} /$ mean $)$ of the slopes from duplicate bottles ranged similarly between the euphotic zone $(0.1$ to $45 \%$; mean $\pm \mathrm{SD}=15 \pm$ $15 \%$ ) and the mesopelagic zone (1 to $47 \%$; mean $\pm \mathrm{SD}=18 \pm 18 \%$ ) except 2 mesopelagic data of 51 and $63 \%$. 
Grazing rates were calculated by multiplying the ratio of bacterial abundances to FLB by the mean values of ingested FLB $\mathrm{l}^{-1} \mathrm{~h}^{-1}$. Ingestion rates were calculated by dividing grazing rates by HNF abundances. Clearance rates were calculated by dividing ingestion rates by bacterial abundances.

The validity of our estimates of ingestion rates was tested by comparing the standard protocol estimates (the method of Sherr et al. 1987) with estimates according to a new protocol proposed by González (1999). It has been shown that ingestion rates can be calculated from the fraction of HNF with ingested FLB during an FLB uptake experiment and the ratio of FLB to bacteria (Eq. 3 in González [1999]), assuming that the distributions of bacteria and FLB ingested by HNF follow Poisson distributions. Also, to find out if the percentage of actively grazing HNF is low in the mesopelagial, estimates of the fraction of HNF actively grazing on bacteria were calculated according to the method of González (1999). Actively grazing HNF are defined as those ingesting any bacteria (total bacteria = natural bacteria + FLB) during uptake experiments. The fraction of active HNF $\left(F_{\text {active }}\right)$ over a time period was estimated as: $F_{\text {active }}=1-[1 / \exp (I t)]$, where $I$ is the ingestion rate on total bacteria by HNF and $t$ is the incubation time (González 1999).

Bacterial abundance and production. Samples for measurements of bacterial abundance were fixed with $0.2 \mu \mathrm{m}$ filtered, borate-buffered formalin (final conc. of $2 \%)$. Bacteria, stained with DAPI $\left(4^{\prime}, 6\right.$-diamidino-2phenylindole; final conc. of $1 \mathrm{\mu g} \mathrm{ml}^{-1}$ ) and collected on black $0.2 \mu \mathrm{m}$ polycarbonate filters, were counted under UV excitation using an epifluorescence microscope (Porter \& Feig 1980). The biovolumes of bacteria and FLB were determined by microphotographs and slides projected onto a paper screen. Projected slides of fluorescent beads of known diameter $(0.4$ and $1.0 \mu \mathrm{m}$, Polysciences Inc.) were used for calibration (Moran et al. 1991). Bacterial production was measured by the ${ }^{14}$ C-leucine incorporation method (Simon \& Azam 1989, Ducklow et al. 1992). Ten to $30 \mathrm{ml}$ of samples (in triplicate) were dispensed into sterile polypropylene tubes, and ${ }^{14} \mathrm{C}$-leucine (sp. act. $=315 \mathrm{mCi} \mathrm{mmol}^{-1}$ ) was added to the tubes at $10 \mathrm{nM}$ (final conc.). All tubes were incubated in the dark for 1 to $2 \mathrm{~h}$ at in situ water temperature and atmospheric pressure. Formalinkilled samples (final conc. of $2 \%$ ) served as blanks. After incubation, ${ }^{14} \mathrm{C}$-leucine incorporation was stopped by adding $2 \%$ formalin. The samples were extracted with ice-cold trichloroacetic acid (TCA, final conc. of $5 \%$ ) for $15 \mathrm{~min}$. The extracted samples were kept cool, filtered onto $0.45 \mu \mathrm{m}$ cellulose nitrate filters (Whatman), and rinsed 3 times with $5 \mathrm{ml}$ of $5 \%$ icecold TCA and subsequently 3 times with $5 \mathrm{ml}$ of $80 \%$ ice-cold ethanol. The filters were placed into scintilla- tion vials and dissolved in $1 \mathrm{ml}$ of ethyl acetate. Ten $\mathrm{ml}$ of liquid scintillation cocktail (Lumagel ${ }^{\circledR}$ ) was added and the samples were radioassayed. The incorporated radioactivity was converted to cell number using a conversion factor of $0.18 \times 10^{18}$ cells mol $^{-1}$ leucine incorporated (Ducklow et al. 1992).

Other analyses. Water temperature was measured by a CTD system (SBE911, Seabird). The euphotic depth was estimated by multiplying the Secchi depth by 2.7 . Linear regression, multiple regression and Student's $t$-test analyses were performed using SPSS for Windows (Version 8.0: SPSS Inc. 1997). To test whether the relationships between 2 variables in the euphotic, lower epipelagic and mesopelagic zones were identical, a multiple regression model with group variables (e.g. $Z_{1}$ and $Z_{2}$, each employing the values of 0 and 1 ) and interaction terms $\left(Z_{1} X\right.$ and $\left.Z_{2} X\right)$ was analyzed. We assigned different values to $Z_{1}$ and $Z_{2}$ for the different zones (i.e. euphotic: 0 and 0 , lower epipelagic: 1 and 0 , mesopelagic: 0 and 1 , respectively). The adopted model is:

$$
Y=\beta_{0}+\beta_{1} X+\beta_{2} Z_{1}+\beta_{3} Z_{2}+\beta_{4} Z_{1} X+\beta_{5} Z_{2} X
$$

where $Y$ is the dependent and $X$ the independent variable, and $Z_{1}$ and $Z_{2}$ are group variables representing zones. We removed insignificant coefficients by a stepwise regression method and then obtained the best model which described the regression functions for each zone (Neter et al. 1996).

\section{RESULTS}

\section{Vertical profiles of temperature, bacteria and HNF variables}

In the surface layer, water temperature ranged from 10.4 to $25.7^{\circ} \mathrm{C}$, and decreased roughly linearly down to $100 \mathrm{~m}$ (Fig. 2A). A steep decline from 16.8 to $1.3^{\circ} \mathrm{C}$ was recorded between 100 and $200 \mathrm{~m}$. Temperature variations at these depths seemed to be associated not only with seasonal variations but also with intense upwelling. In July 1996 at $100 \mathrm{~m}$ depth at Stn B, water temperature was $2.7^{\circ} \mathrm{C}$ compared to $9.2^{\circ} \mathrm{C}$ in April 1996 and $13.1^{\circ} \mathrm{C}$ in May 1996. At depths of 200 to $500 \mathrm{~m}$, water temperature varied from 0.4 to $6.4^{\circ} \mathrm{C}$. The euphotic depth ranged from $27 \mathrm{~m}$ (at Stn J in March 1997) to $81 \mathrm{~m}$ (at Stn M in September 1997) and was shallower than $50 \mathrm{~m}$ in 21 out of 23 measurements. Bacterial abundance in the euphotic zone ranged from $0.2 \times 10^{9}$

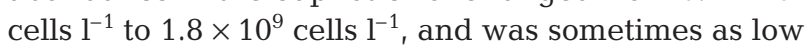
as that at $200 \mathrm{~m}$ depth (Fig. 2B). Bacterial abundance decreased with increasing depth from 0.2 to $1.2 \times 10^{9}$ cells $\mathrm{l}^{-1}$ at $100 \mathrm{~m}$ to $0.1-0.5 \times 10^{9}$ cells l$^{-1}$ at $200 \mathrm{~m}$, and 0.1 to $0.2 \times 10^{9}$ cells $^{-1}$ at $500 \mathrm{~m}$ depth. Bacterial produc- 
tion generally showed a rapid decline below the mixed layer, and then gradually decreased further below this (Fig. 2C). The values ranged from $0.5 \times 10^{6}$ to $37 \times 10^{6}$ cells $\mathrm{l}^{-1} \mathrm{~h}^{-1}$ in the euphotic zone and from $0.1 \times 10^{6}$ to $4 \times 10^{6}$ cells $\mathrm{l}^{-1} \mathrm{~h}^{-1}$ in the mesopelagic zone.
HNF abundance in the euphotic zone varied by an order of magnitude from $0.4 \times 10^{6}$ to $7.5 \times 10^{6} \mathrm{HNF} \mathrm{l}^{-1}$, while in the mesopelagic zone it varied from 0.1 to 0.4 $\times 10^{6} \mathrm{HNF}^{-1}$, with decreasing variation in HNF abundance with increasing depth (Fig. 2D). HNF ingestion
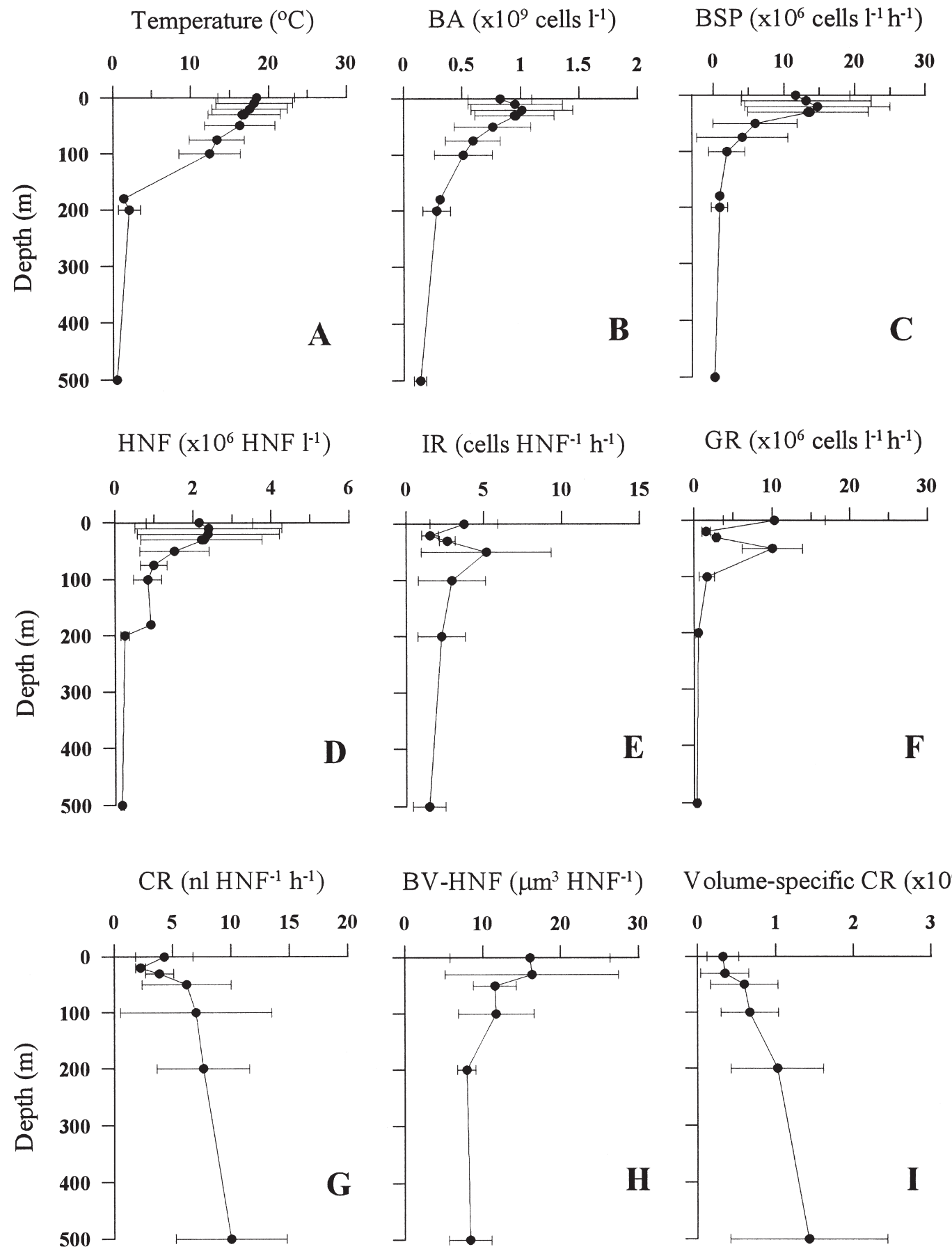

Fig. 2. Depth-profiles of means of (A) water temperature, (B) bacterial abundance (BA), (C) bacterial secondary production (BSP), (D) heterotrophic nanoflagellate (HNF) abundance, (E) ingestion rates (IR), (F) grazing rates (GR), (G) clearance rates (CR), (H) cell-biovolume (BV) of HNF, and (I) volume-specific CR in the East Sea. Data are means \pm 1 SD from April 1996, May 1996, July 1996, March 1997, July 1997 and September 1997 cruises combined. When bars are not shown, 1 SD is less than size of symbol 
rates in the euphotic zone ranged from 1 to 8 cells $\mathrm{HNF}^{-1} \mathrm{~h}^{-1}$, and in the mesopelagic zone from 1 to 5 cells $\mathrm{HNF}^{-1} \mathrm{~h}^{-1}$ (Fig. 2E). Subsurface maxima of HNF ingestion rates were usually observed at 50 to $100 \mathrm{~m}$ depth, except on July 1997 when a surface maximum was found. HNF grazing rates in the euphotic zone varied widely from $0.8 \times 10^{6}$ to $23.3 \times 10^{6}$ cells $\mathrm{l}^{-1} \mathrm{~h}^{-1}$, and in the mesopelagic zone varied from 0.1 to $1.1 \times$ $10^{6}$ cells $\mathrm{l}^{-1} \mathrm{~h}^{-1}$ (Fig. 2F). They were consistently higher in the euphotic zone than in the mesopelagic zone in all cruises. HNF clearance rates in both the euphotic and mesopelagic zones had a similar range of 1 to $11 \mathrm{nl}$ $\mathrm{HNF}^{-1} \mathrm{~h}^{-1}$ (Fig. 2G), but often (2 out of 13 measurements) high clearance rates (14 to $16 \mathrm{nl} \mathrm{HNF}^{-1} \mathrm{~h}^{-1}$ ) were found in the mesopelagial. Mean biovolumes of HNF ranged from 5 to $48 \mu^{3}$ in the euphotic zone, and those in the mesopelagial from 6 to $11 \mu^{3}$ (Fig. $2 \mathrm{H}$ ). Mean biovolumes of FLB and marine bacteria were comparable, ranging from 0.07 to $0.20 \mu^{3}$ and from 0.05 to $0.34 \mu^{3}$, respectively (data not shown). Only in May 1996 was the mean biovolume of FLB $\left(0.11 \mu^{3}\right)$ larger than that of bacteria $\left(0.07 \mu^{3}\right.$, see 'Discussion'). Volume-specific HNF clearance rates in the euphotic and mesopelagic zones were within a similar range $\left(0.1\right.$ to $\left.1.0 \times 10^{6} \mathrm{~h}^{-1}\right)$. Two samples showed high volume-specific clearance rates $\left(1.8\right.$ to $\left.2.6 \times 10^{6} \mathrm{~h}^{-1}\right)$ in the mesopelagic zone (Fig. 2I). In the lower epipelagic zone (i.e. between the euphotic zone and the mesopelagic zone), in most cases the above variables had values intermediate to those of the euphotic and mesopelagic zones (Fig. 2).

\section{Comparisons of HNF variables in euphotic and mesopelagic zones}

HNF ingestion rates did not seem to be statistically different between the euphotic and mesopelagic zones on any cruise (Table 1). However, HNF clearance rates often seemed to be higher in the mesopelagic zone than in the euphotic zone in April 1996, March 1997 and September 1997 (Table 1). In other cruises, HNF clearance rates were statistically not different between the 2 zones. Volume-specific clearance rates were not different between the mesopelagic zone and the euphotic zone in May and July 1996 and March 1997 (Table 1). Thus, HNF ingestion rates seemed to be similar in both zones, but clearance rates and volume-specific clearance rates were either similar or sometimes enhanced in the mesopelagic zone.

\section{Relationships between HNF and bacteria in the mesopelagic zone}

Grazing rates were only significantly correlated with bacterial abundance $\left(r^{2}=0.48, p=0.008\right.$; see Fig. 3A) and water temperature $\left(r^{2}=0.40, p=0.020\right.$; not shown in Fig. 3). Grazing rates in most cases were either higher than bacterial production or a large fraction thereof (see Fig. 3B). Bacterial abundance and HNF abundance were weakly $\left(\mathrm{r}^{2}=0.16, \mathrm{p}<0.06\right)$ correlated (see Fig. 3C). Multiple regression analysis with group variables showed that the relationships between graz-

Table 1. Heterotrophic nanoflagellates (HNF). Comparison of ingestion rates, clearance rates, and volume-specific clearance rates measured in euphotic and mesopelagic zones of East Sea. Values are mean $\pm 1 \mathrm{SD}$, with numbers in parentheses. Student's $t$-test assessed whether mean values were different between 2 zones; $p$-values $<0.05$ represent significant differences between 2 zones. nd: not determined

\begin{tabular}{|c|c|c|c|c|c|c|c|c|c|}
\hline \multirow[t]{2}{*}{ Date } & \multicolumn{3}{|c|}{$\begin{array}{l}\text { Ingestion rates } \\
\left(\text { cells } \mathrm{HNF}^{-1} \mathrm{~h}^{-1}\right)\end{array}$} & \multicolumn{3}{|c|}{$\begin{array}{l}\text { Clearance rates } \\
\left(\mathrm{nl} \mathrm{HNF} \mathrm{HN}^{-1} \mathrm{~h}^{-1}\right)\end{array}$} & \multicolumn{3}{|c|}{$\begin{array}{l}\text { Volume-specific clearance rates } \\
\qquad\left(\times 10^{6} \mathrm{~h}^{-1}\right)\end{array}$} \\
\hline & Euphotic & Mesopelagic & $\mathrm{p}$ & Euphotic & Mesopelagic & $\mathrm{p}$ & Euphotic & Mesopelagic & $\mathrm{p}$ \\
\hline 9-14 Apr 1996 & $\begin{array}{l}2.7 \pm 1.0 \\
(4)\end{array}$ & $\begin{array}{l}1.6 \\
(1)\end{array}$ & nd & $\begin{array}{c}2.9 \pm 1.0 \\
(4)\end{array}$ & $\begin{array}{l}5.8 \\
(1)\end{array}$ & nd & $\begin{array}{c}0.15 \pm 0.03 \\
(4)\end{array}$ & $\begin{array}{c}1.02 \\
(1)\end{array}$ & nd \\
\hline 27-31 May 1996 & $\begin{array}{c}5.6 \pm 1.9 \\
(4)\end{array}$ & $\begin{array}{c}2.6 \pm 1.9 \\
(4)\end{array}$ & 0.075 & $\begin{array}{c}6.5 \pm 2.5 \\
(4)\end{array}$ & $\begin{array}{c}8.7 \pm 6.3 \\
(4)\end{array}$ & 0.538 & $\begin{array}{c}0.47 \pm 0.23 \\
(4)\end{array}$ & $\begin{array}{c}1.25 \pm 1.02 \\
(4)\end{array}$ & 0.185 \\
\hline 23-30 Jul 1996 & $\begin{array}{l}4.5 \pm 2.7 \\
(3)\end{array}$ & $\begin{array}{c}1.5 \pm 0.9 \\
(2)\end{array}$ & 0.246 & $\begin{array}{c}6.0 \pm 1.6 \\
(3)\end{array}$ & $\begin{array}{l}7.0 \pm 4.4 \\
\quad(2)\end{array}$ & 0.802 & $\begin{array}{c}0.42 \pm 0.16 \\
(3)\end{array}$ & $0.82 \pm 0.51$ & 0.459 \\
\hline 10-16 Mar 1997 & $\begin{array}{c}2.2 \pm 1.0 \\
(4)\end{array}$ & $\begin{array}{l}2.7 \pm 1.5 \\
(3)\end{array}$ & 0.622 & $\begin{array}{c}3.3 \pm 1.0 \\
(4)\end{array}$ & $\begin{array}{l}11.7 \pm 2.1 \\
(3)\end{array}$ & 0.001 & $\begin{array}{c}0.38 \pm 0.22 \\
(4)\end{array}$ & $\begin{array}{c}1.36 \pm 0.62 \\
(2)\end{array}$ & 0.254 \\
\hline 22 Sep -1 Oct 1997 & $\begin{array}{c}1.5 \pm 0.5 \\
(3)\end{array}$ & $\begin{array}{c}1.0 \pm 0.5 \\
(3)\end{array}$ & 0.261 & $\begin{array}{c}2.3 \pm 0.4 \\
(3)\end{array}$ & $\begin{array}{c}6.2 \pm 1.6 \\
(3)\end{array}$ & 0.014 & nd & nd & nd \\
\hline
\end{tabular}


ing rates and HNF abundance in the euphotic, lower epipelagic and mesopelagic zones were identical (Fig. 3D, Table 2). For other variables, slopes of the relationships in each zone were the same (Fig. 3, Table 2).
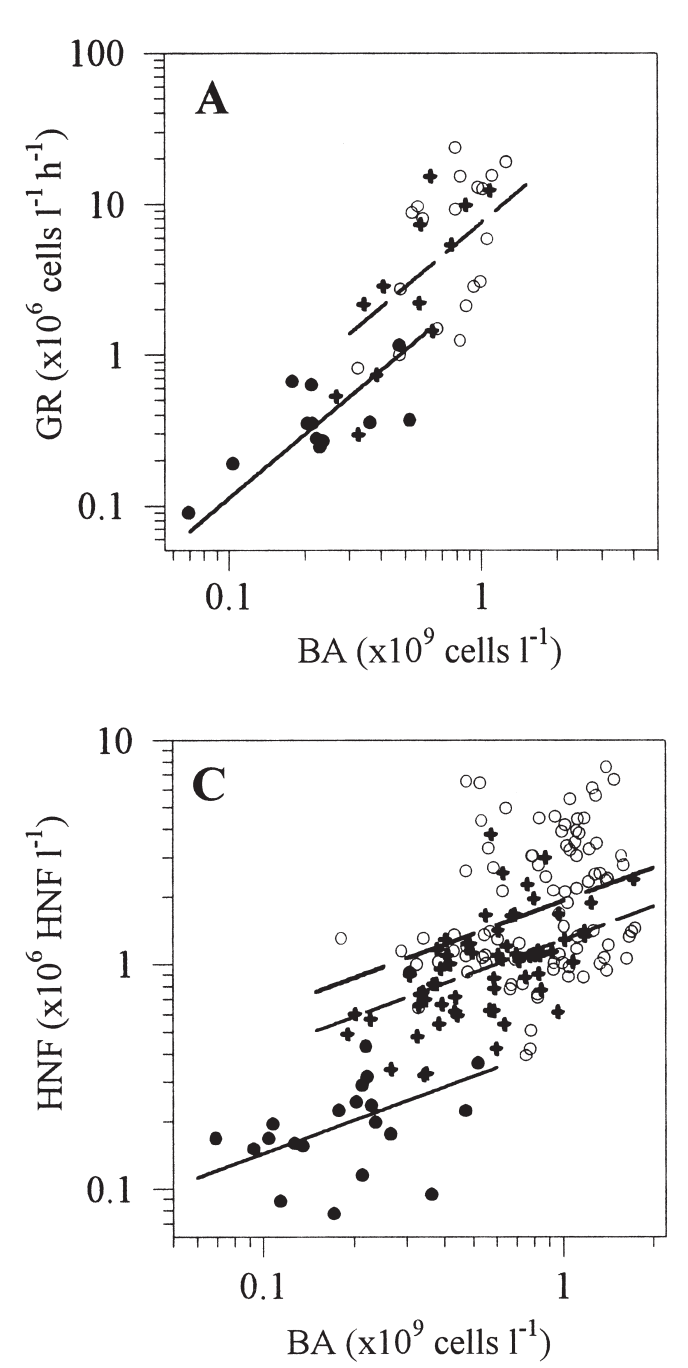

Fractions of active HNF

The fractions of active HNF during the incubation time (called hereafter \% active HNF) varied in the

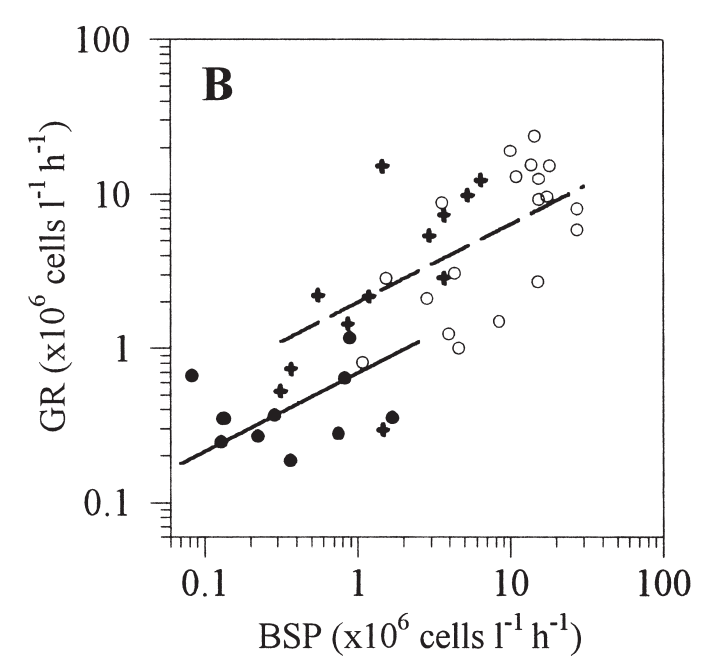

Fig. 3. Scatter plots of (A) bacterial abundance (BA) vs grazing rate (GR), (B) bacterial secondary production (BSP) vs GR, (C) BA vs heterotrophic nanoflagellate (HNF) abundance, and (D) HNF abundance vs GR. Samples were from euphotic (O), lower epipelagic $(\downarrow)$, and mesopelagic $(\bullet)$ zones of the East Sea. Regression lines represent best equations for each zone

Table 2. Heterotrophic nanoflagellates (HNF). Best models selected by stepwise regression method (significance level, $\alpha=0.05$ ), coefficients of determination $\left(\mathrm{r}^{2}\right), F$-statistics, and p-values. Analyses tested whether relationships between 2 variables in euphotic, lower epipelagic and mesopelagic zones were identical. Adopted model was: $Y=\beta_{0}+\beta_{1} X_{1}+\beta_{2} Z_{1}+\beta_{3} Z_{2}+\beta_{4} Z_{1} X+$ $\beta_{5} Z_{2} X$. We assigned different values to $Z_{1}$ and $Z_{2}$ for different zones (euphotic: 0,0 ; lower epipelagic: 1,$0 ;$ mesopelagic: 0,1 ). Common-log transformed data were used for each variable

\begin{tabular}{|c|c|c|c|c|c|}
\hline$Y$ variable & $X$ variable & Selected model & $\mathrm{r}^{2}$ & $F$ & $\mathrm{p}$ \\
\hline HNF abundance & Bacterial abundance & $Y=0.28+0.49 X-0.17 Z_{1}-0.63 Z_{2}$ & 0.62 & 94.2 & $<0.0001$ \\
\hline Grazing rates & Bacterial production & $Y=0.30+0.51 X-0.46 Z_{2}$ & 0.68 & 44.5 & $<0.0001$ \\
\hline Grazing rates & Bacterial abundance & $Y=0.88+1.41 X-0.42 Z_{2}$ & 0.72 & 54.8 & $<0.0001$ \\
\hline Grazing rates & HNF abundance & $Y=0.39+1.22 X$ & 0.81 & 180.5 & $<0.0001$ \\
\hline
\end{tabular}


Table 3. Percentages of active heterotrophic nanoflagellates (HNF) in euphotic and mesopelagic zones, estimated according to González (1999). Values are mean $\pm 1 \mathrm{SD}$ (range; n). Student's $t$-test assessed whether mean values were different between 2 zones; p-values $<0.05$ represent significant differences between 2 zones. nd: not determined

\begin{tabular}{|lccc|}
\hline \multirow{2}{*}{ Date } & \multicolumn{3}{c|}{ \% active HNF } \\
& Euphotic zone & Mesopelagic zone & $\mathrm{p}$ \\
\hline 9-14 Apr 1996 & $68 \pm 17$ & 40 & nd \\
& $(49-86 ; 4)$ & $(-; 1)$ & \\
27-31 May 1996 & $91 \pm 9$ & $55 \pm 25$ & 0.057 \\
& $(78-98 ; 4)$ & $(4)$ & \\
23-30 Jul 1996 & $84 \pm 12$ & $43 \pm 11$ & 0.032 \\
& $(77-98 ; 3)$ & $(35-51 ; 2)$ & \\
10-16 Mar 1997 & $63 \pm 21$ & $65 \pm 20$ & 0.944 \\
& $(33-77 ; 4)$ & $(42-79 ; 3)$ & \\
22 Sep -1 Oct 1997 & $50 \pm 12$ & $34 \pm 10$ & 0.142 \\
& $(37-60 ; 3)$ & $(22-41 ; 3)$ & \\
& & & \\
\end{tabular}

mesopelagial from 22 to $79 \%$ and in the euphotic zone from 33 to $98 \%$ (Table 3). Actively grazing HNF often comprised similar portions in both the mesopelagic and the euphotic zones. In July 1996, the \% active HNF were significantly different between the euphotic and mesopelagic zones: An average of $84 \%$ of the HNF community in the euphotic zone ingested bacteria compared to $43 \%$ in the mesopelagial (Table 3). Percentages of active HNF showed significant relationship with clearance rates both in the euphotic and

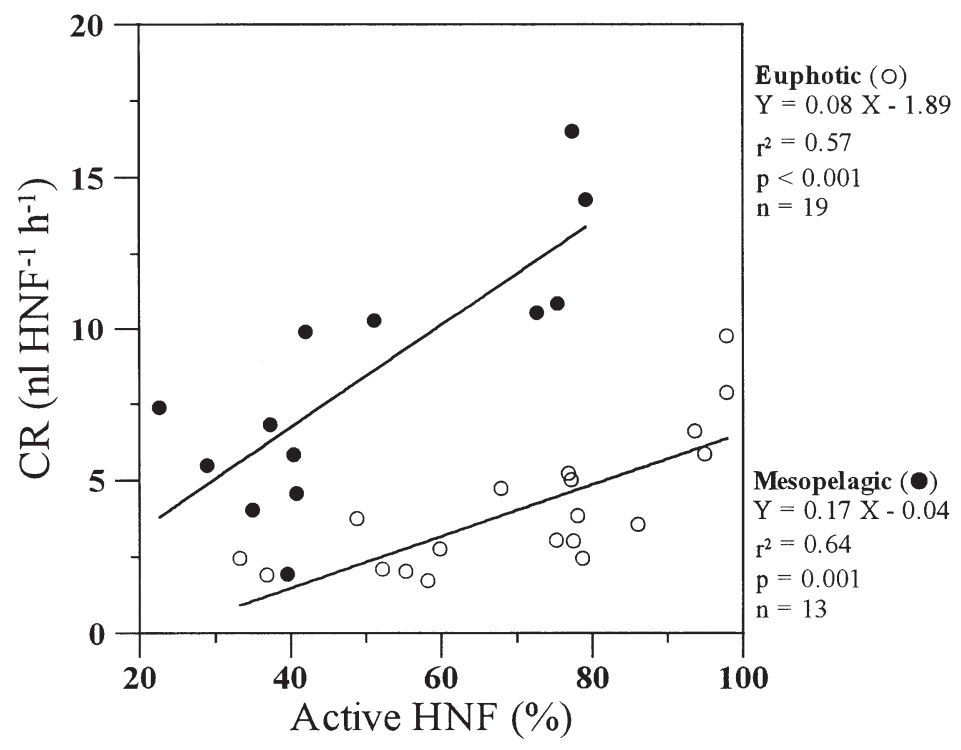

Fig. 4. Scatter plots of clearance rates (CR) vs percentage active HNF in samples from euphotic $(O)$ and mesopelagic $(\bullet)$ zones of East Sea mesopelagic zones (Fig. 4), but with different slopes and $y$-axis intercepts. However, clearance rates did not correlate $(p>0.05)$ with total active HNF abundance in either zone (data not shown).

\section{DISCUSSION}

Unexpectedly, no significant differences were observed between ingestion rates in the euphotic and mesopelagic zones in the present study. Further, HNF clearance rates and volume-specific HNF clearance rates were generally in the same ranges in the 2 zones and often higher in the mesopelagic zone. This is intriguing because slow growth (11 to 89 d doubling time calculated on the basis of bacterial abundance and production) and low abundance of mesopelagic bacteria $\left(0.1\right.$ to $0.5 \times 10^{9}$ cells $\left.1^{-1}\right)$ seemed to present unfavorable conditions for the ingestion of bacteria by HNF (Peters 1994). In seawater samples incubated for 30 to $60 \mathrm{~h}, \mathrm{HNF}$ increased their clearance rates (15 to $20 \mathrm{nl} \mathrm{HNF}^{-1} \mathrm{~h}^{-1}$ ) at the optimal conditions of maximum bacterial abundance, and under unfavorable conditions with minimum bacterial abundance (i.e. at starving status) reduced their clearance rates (5 to $10 \mathrm{nl}$ $\mathrm{HNF}^{-1} \mathrm{~h}^{-1}$ ) (Andersen \& Fenchel 1985). Thus, reduced clearance rates of HNF would be expected in the mesopelagial, but our result did not agree with this prediction. This phenomenon might suggest innately high clearance rates by mesopelagic HNF, and maybe different species occur in the mesopelagial. The high clearance rate in mesopelagic HNF would be advantageous to HNF survival during conditions of low abundance and slow growth of bacteria in the mesopelagial.

Another surprising observation was that similar percentages of active HNF were frequently found in both pelagic zones. Actively ingesting HNF during the incubation period occurred persistently in the mesopelagic samples, with a range of 22 to $79 \%$ of $\mathrm{HNF}$ assemblages comparable to 33 to $98 \%$ active HNF values found in the euphotic zone of the East Sea and 11 to $99 \%$ active HNF in marine samples (González 1999). These results indicate that mesopelagic HNF are still active and survive in the mesopelagial. Furthermore, a ca 4 -fold variation in \% active HNF (Fig. 4) suggests that mesopelagic HNF may adapt their physiological state to the changing conditions in the mesopelagial. Also, close relationships between HNF clearance rates and \% active HNF for both the euphotic and mesopelagic zones indicate that with more active members in the HNF assem- 
blages, HNF increased clearance rates in both zones. This is striking, because the measurements in each pelagic zone were from different seasons, depths and prey conditions, presumably encompassing diverse HNF assemblages. Varying their clearance rates according to the fractions of actively grazing HNF available in the assemblages would enable HNF to adjust their consumption of bacteria in the mesopelagial.

Similar rates of HNF clearance and comparable percentages of active HNF in both pelagic zones indicate that low HNF grazing rates in the mesopelagial would not be due to low levels of activity by mesopelagic HNF and low \% of active HNF, but to low abundance and flux of bacteria to mesopelagic HNF. Consistently, the ratios of HNF grazing to bacterial production were larger than 1 in $67 \%$ of the samples (Fig. 3B). Such high ratios in the mesopelagial suggest that mesopelagic HNF may consume other particles and bacterial production exported from the euphotic zone. Alternatively, bacterial production may be underestimated. However, the possibility of underestimating bacterial production would be remote (see below). Thus, in general, HNF seem to be the major cause of bacterial mortality and to overwhelmingly control the growth of bacteria in the mesopelagial in the study area, and presumably in other oceanic systems as well.

Regression analyses of HNF variables with other variables showed that only HNF grazing on bacteria in the mesopelagic zone depended significantly on bacterial abundance and water temperature. The dependence of HNF grazing on bacterial abundance and water temperature is consistent with other HNF grazing model available in the literature (Vaqué et al. 1994). However, HNF grazing on bacteria was not significantly correlated with bacterial production and HNF abundance in the mesopelagic zone. Analyses of a multiple regression model with group variables and interaction terms showed that responses of HNF grazing rates to changes in HNF abundance, bacterial abundance and bacterial production are similar in the euphotic, lower epipelagic and mesopelagic zones (Fig. 3, Table 2). This suggests to us that significantly similar relationships between HNF grazing rates and bacterial production and HNF abundance exist in the mesopelagial, and that the lack of significant relationships in the mesopelagial would be due to the small number of samples in our study. Probably, dependence of HNF grazing on bacterial production would also hold in the mesopelagial, and large-growing bacteria would be grazed selectively by HNF (González et al. 1990, 1993) in the mesopelagial.

The above scenarios could be affected if we underestimated bacterial production or overestimated HNF grazing in the mesopelagic samples. It is unlikely that bacterial production was underestimated: a conversion factor of $1.8 \times 10^{17}$ cells (mol leucine incorporated) ${ }^{-1}$ for
${ }^{14} \mathrm{C}$-leucine incorporation seems reasonable since conversion factors obtained empirically for the euphotic samples were close to this (data not presented), and since extracellular isotope dilution of leucine would be negligible due to undetectable leucine concentration in the mesopelagic zone (Park et al. 1995). Were we to use lower conversion factors for the mesopelagic zone (i.e. no intracellular isotope dilution of leucine: Simon et al. 1992), the conclusion of major control of mesopelagic bacteria by HNF would not be affected. Probably, underestimation of bacterial production could come from ingestion and subsequent digestion of bacteria by HNF during the measurements. Using values and relationship in the literature on carbon-based gross growth efficiency (ca 20 to $40 \%$ : Sherr et al. 1987, González et al. 1993) of HNF and the temperature dependence of digestion rate (Sherr et al. 1988), we would calculate that $<2 \%$ of bacterial production was underestimated for 1 to $2 \mathrm{~h}$ incubation (data not shown; also, M. Simon pers. comm.).

Short-term uptake experiments of FLB are rarely applied to oligotrophic aquatic environments (Christaki et al. 1999, González 1999) since such an approach often lacks sensitivity because of their low bacterial abundance (Sherr et al. 1993). Recently, González (1999) proposed a new protocol for estimating HNF grazing rates from fractions of HNF with ingested FLB, and showed an excellent match with estimates using the standard protocol (according to the method of Sherr et al. [1987]). Furthermore, he anticipated that the new protocol would be useful for aquatic environments with low bacterial abundance. For our mesopelagic as well as our euphotic samples, we obtained optimum correspondence at a slope of 1:1 (Fig. 5) as did González (1999). Thus, the short-term uptake experiments using FLB in our mesopelagic samples seemed effective. The use of different biovolumes of FLB than those of in situ marine bacteria might affect our grazing rates, since it is known that HNF clearance rates are strictly related to bacterial biovolume (González et al. 1990). Thus, biovolume-corrections must be made for measured grazing rates when the mean biovolumes of FLB differ significantly from those of marine bacteria. González (1996) proposed that HNF could be highly effective size-selective grazers for small bacteria $\left(<0.1 \mu^{3}\right)$, and that HNF clearance rates depend on bacterial biovolume in a Monod-like relationship. Since the range of bacterial biovolumes in our study was 0.05 to $0.34 \mathrm{\mu m}^{3}$, use of the proposed model was inviting. However, the clearance rates from this study were much higher than the maximum clearance rate of HNF reported by González (1996), suggesting that direct use of such relationship requires further investigation. Nevertheless, relative biovolumecorrections could be and were approximated: the cor- 


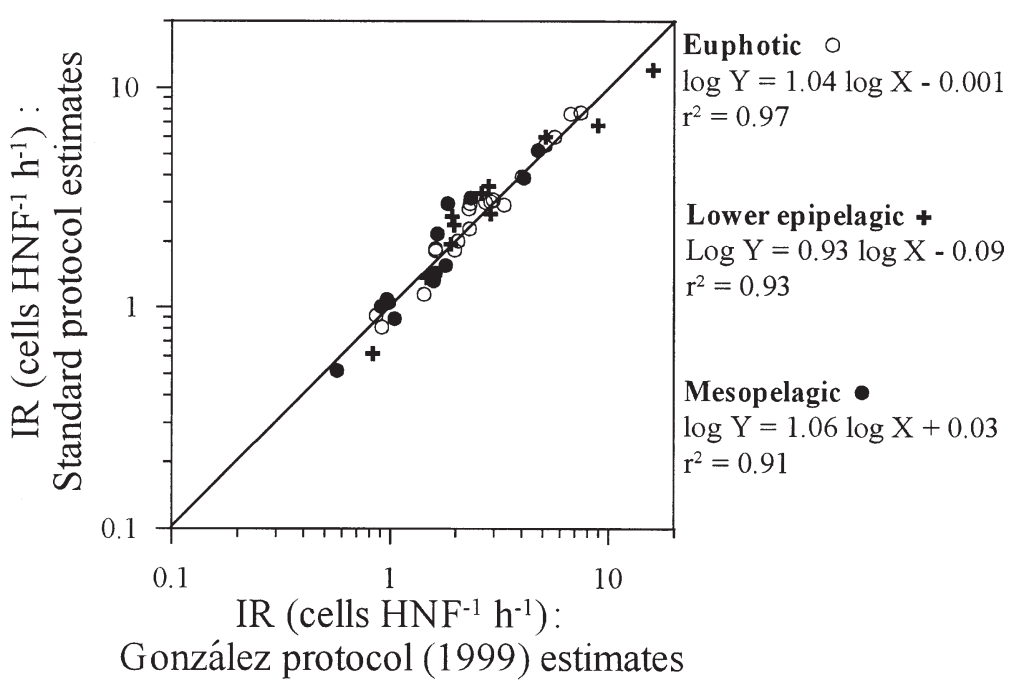

Fig. 5. Comparison of ingestion rates obtained experimentally from FLB (fluorescently labeled bacteria) method of Sherr et al. (1987) and those calculated from fractions of HNF with ingested FLB according to González (1999). Data were from euphotic (O), lower epipelagic (†) and mesopelagic (๑) zones of East Sea. Line represents 1:1 slope

rections did not affect our general conclusions, although changes in the HNF grazing to bacterial production ratios were substantial. After biovolumecorrection, the ratios of HNF grazing to bacterial production in the mesopelagial ranged from 0.12 to 4.47 , and ratios $>1.0$ occurred in 5 out of 12 samples.

In the present study, we assumed that growth rates of mesopelagic bacteria and grazing rates of mesopelagic HNF might not be influenced by incubating mesopelagic samples at atmospheric pressure. There were but few studies available in the literature regarding pressure effects on mesopelagic bacteria. Turley (1993) showed that leucine incorporation by bacteria attached to sinking particles collected from $200 \mathrm{~m}$ depth did not differ at 1 and 100 atm pressure. However, this result might not be directly applicable to our free-living bacteria samples. Recently, Tholosan et al. (1999) reported that pressure effects on bacterial production measured by ${ }^{3} \mathrm{H}$-thymidine incorporation seemed be first evident at $800 \mathrm{~m}$ depth. It thus seems that incubation of our mesopelagic samples at atmospheric pressure did not cause a serious underestimation of bacterial production. However, no information is available about pressure effects on mesopelagic HNF grazing rates. To confirm the above scenario, further work using non-decompressed samples for HNF grazing rates is needed.

Although our conclusions await future confirmation, our results showing active mesopelagic HNF and high grazing pressure by HNF on mesopelagic bacteria have important implications for biogeochemical cycles and microbial food webs in the mesopelagial. Solubilization of a sinking particles mediated by particle-associated bacteria (Smith et al. 1992) provides dissolved organic matter for the growth of free-living bacteria (Cho \& Azam 1988). The largescale production of bacteria would be dominantly channeled to HNF in the mesopelagial, and mesopelagic HNF would respire bacterial organic carbon and regenerate nutrients in a tightly coupled manner, since upon exposure to food-bacteria starved flagellates, irrespective of starvation period, are known to instantly increase respiration within a few minutes of feeding (Fenchel 1982). In addition, mesopelagic HNF would be a link between bacteria and microzooplankton, completing the microbial loop (Azam et al. 1983) in the mesopelagic zone. The survival and significant potential growth of mesopelagic HNF would support the proposed interaction between HNF and aggregates in the mesopelagial (Lochte 1991), and thereby the contribution of mesopelagic HNF to decomposition and fragmentation of aggregates during their settlement through the mesopelagial.

In conclusion, HNF in the mesopelagic zone seem to survive well the low abundance and production of bacteria in this zone, and to exert dominant grazing forces on mesopelagic bacteria at the study site. The HNF would thus play an important role in biogeochemical cycles and energy flow via microbial food-webs in the mesopelagial. The flow of energy through the mesopelagic microbial loop may be limited by availability of bacteria.

Acknowledgements. We thank Dr K. H. Hong (KORDI, Korea Ocean Research \& Development Institute) for providing us with the opportunity to join the AWARES cruises, and the captains and crews of the RV 'Eardo', KORDI, for their cooperation during the cruises. We thank Dr J. M. González for reading our first manuscript and for his constructive comments. We thank 4 anonymous reviewers for their critical and helpful comments. We also thank Dr M. Simon, and Mr R Long, for carefully correcting the English of our revised manuscript. This work was supported (in part) by the BK 21 Project of the Korean Government and the KORDI Program (BSPN 96340-00-1012-4).

\section{LITERATURE CITED}

Andersen P, Fenchel $\mathrm{T}$ (1985) Bacterivory by microheterotrophic flagellates in seawater samples. Limnol Oceanogr 30:198-202

Azam F, Fenchel T, Field JG, Gray JS, Meyer-Reil LA, Thingstad F (1983) The ecological role of water-column microbes in the sea. Mar Ecol Prog Ser 10:257-263 
Caron DA (1983) Technique for enumeration of heterotrophic and phototrophic nanoplankton, using epifluorescence microscopy, and comparison with other procedures. Appl Environ Microbiol 46:491-498

Cho BC, Azam F (1988) Major role of bacteria in biogeochemical fluxes in the ocean's interior. Nature 332:441-443

Cho BC, Azam F (1995) Urea decomposition by bacteria in the Southern California Bight and its implications for the mesopelagic nitrogen cycle. Mar Ecol Prog Ser 122:21-26

Christaki U, Van Wambeke F, Dolan JR (1999) Nanoflagellates (mixotrophs, heterotrophs and autotrophs) in the oligotrophic eastern Mediterranean: standing stocks, bacterivory and relationships with bacterial production. Mar Ecol Prog Ser 181:297-307

Ducklow HW, Kirchman DL, Quinby HL (1992) Bacterioplankton cell growth and macromolecular synthesis in seawater cultures during the North Atlantic spring phytoplankton bloom, May 1989. Microb Ecol 24:125-144

Fenchel T (1982) Ecology of heterotrophic microflagellates. II. Adaptations to heterogeneous environments. Mar Ecol Prog Ser 9:23-33

González JM (1996) Efficient size-selective bacterivory by phagotrophic nanoflagellates in aquatic ecosystems. Mar Biol 126:785-789

González JM (1999) Bacterivory rate estimates and fraction of active bacterivores in natural protist assemblages from aquatic systems. Appl Environ Microbiol 65:1463-1469

González JM, Sherr EB, Sherr BF (1990) Size-selective grazing on bacteria by natural assemblages of estuarine flagellates and ciliates. Appl Environ Microbiol 56:583-589

González JM, Sherr EB, Sherr BF (1993) Differential feeding by marine flagellates on growing versus starving, and on motile versus nonmotile, bacterial prey. Mar Ecol Prog Ser 102:257-267

Lochte K (1991) Protozoa as makers and breakers of marine aggregates. In: Reid PC, Turley CM, Burkill PH (eds) Protozoa and their role in marine processes. Springer-Verlag, Berlin, p 327-346

Moran MA, Wicks RJ, Hodson RE (1991) Export of dissolved organic matter from a mangrove swamp ecosystem: evidence from natural fluorescence, dissolved lignin phenols, and bacterial secondary production. Mar Ecol Prog Ser 76:175-184

Neter J, Kutner MH, Nachtsheim CJ, Wasserman W (1996) Applied linear statistical models. Richard D Irwin Inc, Chicago, p 455-489

Park YC, Son SK, Chung KH, Kim KH (1995) Characteristics of fluorescent organic matter and amino acids composition in the East Sea. J Korean Soc Oceanogr 30:341-354 (in Korean)

Peters F (1994) Prediction of planktonic protistan grazing rates. Limnol Oceanogr 39(1):195-206

Pomeroy LR, Johannes RE (1968) Occurrence and respiration of ultraplankton in the upper 500 meters of the ocean. Deep-Sea Res 15:381-391

Porter KG, Feig YS (1980) The use of DAPI for identification and enumeration of bacteria and blue green algae. Limnol Oceanogr 25:943-948

Editorial responsibility: Otto Kinne (Editor), Oldendorf/Luhe, Germany
Proctor LM, Fuhrman JA (1991) Roles of viral infection in organic particle flux. Mar Ecol Prog Ser 69:133-142

Rassoulzadegan F (1991) Methods for the study of marine microzooplankton. In: Reid PC, Turley CM, Burkill PH (eds) Protozoa and their role in marine processes. SpringerVerlag, Berlin, p 39-57

Sanders RW, Caron DA, Berninger U (1992) Relationships between bacteria and heterotrophic nanoplankton in marine and freshwaters: an interecosystem comparison. Mar Ecol Prog Ser 86:1-14

Sherr EB, Sherr BF (1993) Protistan grazing rates via uptake of fluorescently labeled prey. In: Kemp PF, Sherr BF, Sherr EB, Cole JJ (eds) Handbook of methods in aquatic microbial ecology. Lewis Publishers, Boca Raton, p 695-702

Sherr BF, Sherr EB, Fallon RD (1987) Use of monodispersed, fluorescently labeled bacteria to estimate in situ protozoan bacterivory. Appl Environ Micobiol 53:958-965

Sherr BF, Sherr EB, Rassoulzadegan F (1988) Rates of digestion of bacteria by marine phagotrophic protozoa: temperature dependence. Appl Environ Microbiol 54:1091-1095

Sherr BF, Sherr EB, Pedrós-Alió C (1989) Simultaneous measurement of bacterioplankton production and protozoan bacterivory in estuarine water. Mar Ecol Prog Ser 54: $209-219$

Simon M, Azam F (1989) Protein content and protein synthesis rates of planktonic marine bacteria. Mar Ecol Prog Ser 51:201-213

Simon M, Welschmeyer NA, Kirchman DL (1992) Bacterial production and the sinking flux of particulate organic matter in the subarctic Pacific. Deep-Sea Res 39:1997-2008

Smith DC, Simon M, Alldredge AL, Azam F (1992) Intense hydrolytic enzyme activity on marine aggregates and implications for rapid particle dissolution. Nature 359:139-142

SPSS Inc. (1997) SPSS for Windows, release 8.0, Chicago, IL

Steward GF, Smith DC, Azam F (1996) Abundance and production of bacteria and viruses in the Bering and Chukchi Seas. Mar Ecol Prog Ser 131:287-300

Taylor GT, Karl DM, Pace ML (1986) Impact of bacteria and zooflagellates on the composition of sinking particles: an in situ experiment. Mar Ecol Prog Ser 29:141-155

Tholosan O, Garcin J, Bianchi A (1999) Effects of hydrostatic pressure on microbial activity through a $2000 \mathrm{~m}$ deep water column in the NW Mediterranean Sea. Mar Ecol Prog Ser 183:49-57

Turley CM (1991) Protozoa associated with marine snow and fluff. In: Reid PC, Turley CM, Burkill PH (eds) Protozoa and their role in marine processes. Springer-Verlag, Berlin, p 309-326

Turley CM (1993) The effect of pressure on leucine and thymidine incorporation by free-living bacteria and by bacteria attached to sinking oceanic particles. Deep-Sea Res 40:2193-2206

Vaqué D, Gasol JM, Marrasé C (1994) Grazing rates on bacteria: the significance of methodology and ecological factors. Mar Ecol Prog Ser 109:263-274

Young RW (1983) Oceanic bioluminescence:an overview of general functions. Bull Mar Sci 33:829-845

Submitted: March 31, 1999; Accepted: May 5, 2000

Proofs received from author(s): October 9, 2000 